\title{
Access to Utilizing Water Resources and Conflicts of Interest in Indonesia's Law
}

\author{
Ramziati* $^{*} \quad$ Yulia Jumadiah Nuribadah \\ Lecturer of Faculty, of Law, of Malikussaleh University, Lhokseumawe, Aceh Utara, Aceh Indonesia
}

\begin{abstract}
Water is an important element for the existence of humans and other living things on earth. Hence, water resources become an important object of concern today. Development that prioritizes economic progress in various regions in Indonesia has led to increased exploitation of water resources. Therefore, there is a monopoly on the use of water resources for business purposes, resulting in the negligence of opportunities for the community to utilize water resources. Meanwhile, the water resources are originally water resources which become the sole foundation of the community to meet their needs for water both for domestic and agricultural needs. Although the management of water resources in Indonesia has received serious attention since 1974 with the adoption of Law No. 11 of 1974 concerning Irrigation, in 2015, Government Regulation No.121 of 2015 concerning Water Resources Management (PP PSDA) has been issued. The reality is that there are still conflicts of interest in the use of water resources between business and community interests because the use of water resources is still dominated by business interests. This fact hampers the purpose of exploiting water resources for the welfare of the citizens of the community. This article intends to figure out what causes the conflicts between business' interest and the community's interest in the use of water resources. The purpose of this study is to analyze more deeply the causes of the conflicts between business' interest and the community's interest in the use of water resources. This legal research used a normative juridical approach using primary data and secondary data. Data analysis was carried out in a qualitative descriptive manner by critically analyzing the data obtained in order to get input for improvement. Collecting Primary data as secondary data were done through literature review. This study concludes that there are two factors that cause conflicts of interest in the use of water resources in Indonesia. Inclusive habit of the community in utilizing water resources, creating an ineffective use of it and the absence of the balance principle in Article 2, point (1) PP PSDA are the two dominant factors in the conflict of interests between the community and business in Indonesia in the use of water resources. It is recommended that the government take proactive steps to bridge these two interests and revise Article 2, point (1) of the PP PSDA by adding the principle of balance, so that conflicts of interest between business and community do not continue and justice for business and community interests can be realized.
\end{abstract}

Keywords: Utilization, water resources, conflict of interest, Law, Indonesia.

DOI: $10.7176 / J L P G / 81-02$

\section{Introduction}

Water has become an important issue in recent years and the water crisis has become a crucial problem faced by humans in the future (World Economic Forum, 2012). Water demand is increasing due to the rising population rate, urbanization, the progress of economic development accompanied by an increase in people's living standards (Unesco, 2014). Hundreds of millions of people live without access to enough water. The scarcity of water is constantly being experienced in China, India, Libya, Pakistan, Saudi Arabia, Somalia, and Yemen. Occurrences hit all parts of the world regularly which makes millions of lives and livelihoods threatened (Joshua Busby, 2017).

Likewise, the progress of economic development does not pay attention to the preservation of natural resources and natural conditions that can affect the environment and natural resources in it either (Abdoellah, O.S. 2002). Utilization of water resources tends to be exploitative that place business interests as the main consideration in development (C.Elliot \& F. Quinn, 2001).

Fulazzaky M.A in his article entitled "Conflict of Interest Water Resource Management," describes a management or utilization of water resources through principles that provide businesses with potential waterrelated problems, identification of water availability and various water-related problems (Fulazzaky,M.A, 2014).

Ambar Istayani also in her study entitled "Dynamics of Water Resource Management in the Era of Regional Autonomy, Case Study in Tajuk Village, Getasan Sub-District, Kab. Semarang", concluded that the inability to distribute water for business interests and community interests resulted in conflicts of water-based interests in Indonesia. Therefore, natural resource utilization needs to be carried out in a balance among various interests (Ambar Istiyani, 2014).

According to the distributive justice theory by Aristotle, utilization of natural resources and respect in a community is to realize justice which aims to achieve balance (Vecchio G.V., 1982). However, the reality in Indonesia is that the shifting function in using water resources originally only used for the purpose of fulfilling domestic water needs and agriculture is mostly used for business purposes. Business activities that generally use 
water as raw material can be seen in the misuse of water and mineral water companies and Regional Water Companies (PDAM). That eventually becomes one of the causes of the water resource use which is not based on the principle of balance between the interests of the community and business, having triggered a conflict of water-based interests in Indonesia. In 2015, the Indonesian government issued government regulation No. 121 of 2015 concerning Water Resources Management (PP Water Resources Concession). The purpose of exploiting water or water resources as stated in Article 11 of Law Number 11 of 1974 concerning Irrigation is to improve people's welfare carried out by the government, both central and regional. Utilization of both carried out by legal entities, social bodies and or individuals that are guided by the principle of joint business and family as stipulated in the government regulation on the exploitation of water resources, namely: with the principle of not disturbing, disregarding and negating people's rights to water; state protection of people's rights to water; environmental preservation as one of human rights; absolute supervision and control of water by state; the main priority for exploitation of water given to state-owned enterprises or regional-owned enterprises; granting permits for exploitation of water resources and permits for exploiting ground water to private businesses which can be carried out under certain and strict conditions after all these principles have been met and there is still availability of water. Although the provisions governing the use of water resources have been regulated in such a way, in reality the conflict of interest in the use of water resources between the community and business continues to occur. Therefore, this article intends to analyze the factors of conflict of interest between the community and business to find solutions for these conflicts.

\section{Research Method}

This study used a legal research method with a normative juridical approach. This analytical and critical data is needed to be able to find out the issues that occur, as well as revise laws relating to access to utilization of water resources. According to Chartterjee this method is used to enable researchers to criticize, revise and suggest amendments, cancellations, and legal changes that are weak and less effective (Chartterjee, 2000), in the context of writing this article related to the provisions regarding exploitation or utilization of water resources.

\section{Utilization of natural resources and water resources}

Natural resources include all resources found in nature and all systems that can be useful for humans, technology, economics and social (Flavin C., 2002). World Trend Report describes natural resources as a function of production, meaning as a supply of material found in the environment and is natural, rare and has economic value in its production and use either when it is in the state of raw or after being processed. Paying attention to feasibility is "economically useful," such as water sea, natural material that covers most of the earth's surface, but the material is intrinsically valuable or directly limited to use or production (World Trade Report, 2010).

Water resources are one of the natural resources found in the universe and important resources that exist in the environment. It is also a natural and important resource in the ecosystem, that is, the environment which has close interrelationships (mutual relations) between living things and natural factors with each other. Natural resources include large public spaces and all natural resources in them, together with all commodities produced (Kartodihardjo, H. 2008).

Water resources can be in the form of places of water both above ground and underground. The place or container of water storage needs to be maintained and looked after so that its preservation is maintained. The word 'sustainable' means to remain as before, unchanging, eternal form of a situation. Particularly, those related to this study are water resources that are constant and unchanging. The division of resources as part of respect in a community should be based on the principle of balance to bring justice to all parties.

According to distributive justice theory introduced by Aristotle, the purpose of justice is to achieve balance even though not through equal distribution. In the same principle of freedom, each person has the right to individual freedom equal to the rights of others and equal opportunities to obtain good and beneficial things, and it involves everyone to bear the consequences (losses) of an action (Aristotle in C.Elliot \& F. Quinn, 2001). In the context of access to natural resources, especially water, everyone has the same rights as other people to gain access to water, as well as collect together for the loss of the actions of natural resource users. Thus, economic injustice in the community must be regulated to protect parties who are not weak by giving equal opportunity to all people with fair conditions.

The use of water resources which in Indonesian law is known as exploitation is an effort to utilize water resources to meet business needs. The activities carried out should be devoted to the interests, the welfare of the people while creating growth, social justice and the ability to stand on their own strength towards a just and prosperous society based on the Pancasila. But the present reality in Indonesia is the tendency of dominant behavior in utilizing water resources, causing conflicts in the utilization of water resources in the community. Conflicts occur due to violations of rules or background of someone who has deviant behavior. In the perspective of conflict that emphasizes the pluralistic nature of society and the imbalance in the distribution of 
power that occurs between various groups among them, the emergence of conflicts of interest between community and business in the use of water resources occurs because of imbalance distribution among various groups of water resource users. Business institutions have a position that tends to be stronger (superior) so that they benefit more, while people in weak positions (inferior) also struggle to obtain their rights. According to Sorokin, the basis and the core of the inner layers of society is the absence of balance in the distribution of rights and obligations, and the responsibility of social values and direction among community members (Soerjono Soekanto, 1995).

According to Ralf Dahrendorf's conflict theory, the conflicts of interest and compulsion or union that unite the community under various pressures, communities are united by circles in which society is delegated an authority over other parties. The difference in the distribution of authority has always been a determinant of systematic social conflict (Ritzer, G dan Goodman DJ. 2009). This theory understands society in terms of conflict starting from the fact that members of the community consist of two categories, namely those who are in power and who are controlled. This includes structure and essence in a shared life so that it creates different interests and may even contradict each other, thus triggering a collision between them.

Conflict Theory is a perspective that views society as a social system consisting of different interests where there is an attempt to conquer other components in order to fulfill other interests or obtain maximum interests. The good utilization of uncontaminated (maintained) water is a paradigm that views water as a renewable resource, so that the neglect of considerations to preserve its sustainability not properly maintained has implications for the reduction of raw water resources. Thus, efforts to manage water resources and use them effectively are important things to do immediately. Management and utilization of water resources is a part of a water conservation program which fully maintain the existing water resources effectively for the welfare of the community. These activities are needed to minimize exploitation of water resources excessively which will negatively impact the environment such as pollution or damage to water resources (Sallata, M.K, 2015), so that it is needed to have an effective approach for the management of water resources.

\section{The Conflict in the utilization of water resources}

Conflict (Confligo) means strike, destruction or crushing which is caused by differences of opinion among members who have an impact on disputes or conflicts. Sociologically conflict is interpreted as a social process between two or more people, and one of them tries to get rid of the other party to make it weak. Conflict means different interests or a belief that the aspirations of the conflicting parties are not achieved simultaneously.

Conflicts and disasters can have a direct or indirect impact on the social capital and human resources needed to run water-related infrastructure, together with governance, and ensure the social system to remain functioning and water services to be accessible (Donnelly, et al., 2012). Together with government, social or political systems keep water functioning and water services accessible. Conflicts and disasters can have sequential effects and long-term implications for water security, with political, social, economic and environmental consequences (Priyo Utomo, 1993). Improper management will lead to hunger, food insecurity, ecological destruction, and resource-based conflict (Gleick, P. H.,. 1998). Thus, management of natural resources, especially in this case good water resources, become an important thing so that the purpose of exploiting water resources for the realization of a prosperous society becomes a reality.

\section{Conflict of Interest in Utilization of Water Resources in Indonesia}

Conflict of interest in the use of water resources in Indonesia is caused by community habits that are inclusive in utilizing water resource in which particular water resources around the community in a particular area are only used for the benefit of the community just as for their domestic and agricultural needs. That causes the use of water resources that are ineffective (wasteful), as has happened in the community of Umbulan Village and Sidepan village in particular where the societies felt that Umbulan's water resources are theirs that need not to be used by people outside the area, even though the Umbulan water discharge is quite large and could supply 3 (three) Regencies in East Java (Sukriyah Kustanti Moerad, 2016).

According to I Nyoman N, utilization of water resources tend not to pay attention to the principles of the use of water resources such as the principle of prudence, justice, democracy and sustainability (I Nyoman Nurdjaya, 2018). The use of water resources for business purposes is not based on the principle of exploiting water resources such as those that occur in Suwung and Kuta which affects 200 more or $60 \%$ of the watershed to become dry and intrusions occur (ground water that has been contaminated by sea water). This can lead to a water crisis that occurs not only in the quantity of water but also in the quality of water and the potential for surface water that continues to decrease (Walhi, 2012).

The big phenomenon that disturbs the lower middle class is the absolute control of water resources by certain sectors that are not controlled. In addition, the unavailability of patterns, systems, and mechanisms in determining the distribution of water, and the resolution of conflicts of interest that occur receive fair treatment. However, in quantity the availability of water that can be utilized continues to decline due to damage to the 
hydrological cycle and pollution. This condition will encourage people to enter into the water crisis trap which accumulatively can trigger the emergence of horizontal and vertical water conflicts. Ironically, this crucial problem has not been responded to proportionally by policy makers and planners. Examples of conflicts that have occurred have been between farmers and PDAMs in Bandung City, because the water was taken by the PDAM from the Cikalong hydropower outlet as well as increasing flow of water used by PDAMs to increase water supply (Sosiawan, Subagyono, 2009). Therefore, local government intervention is needed to issue regulations regarding the prohibition on the use of surface water for business (Saraswaty, 2013).

In 2015, PP No. 121 of 2015 concerning the Management of Water Resources (PP PSDA) was issued, in Article 2 the principles of exploitation of water resources are stipulated, stating that "the exploitation of water resources is carried out with due regard to the principle: a. do not disturb, override, and negate the people's right to water; b. state protection of people's rights to water; $c$. environmental preservation as one of human rights; $d$. state supervision and control of water is absolute; e. the main priority for exploitation of water is given to stateowned enterprises or regional-owned enterprises; and f. granting permits for exploitation of water resources and permits for exploiting ground water to private businesses can be carried out with certain and strict conditions after the principle as referred to in letter a to letter e is fulfilled and there is still availability of water. "

The principle of exploiting resources does not include the principle of balance, meaning that there is no principle that can be used as a goal to balance business interests and community interests in the field of exploiting air resources. Thus, open opportunities occur for certain parties, making other parties weak (inferior). The principle of balance in the context of this paper is the balance of resources that affect society and the business environment. In addition, the absence of this principle also implies the failure to achieve the goal of exploiting air resources that increase the benefits of natural resources for people's welfare (Article 2 Paragraph (2) PP PSDA) and kinship "(Article 2 paragraph (3) PP PSDA). However, the absence of such principle as stipulated in article 2 paragraph (1) can result in the neglect of the community's sense of sensitivity in exploiting air resources. The resources that can be accessed by all interested parties appropriately for business purposes. If the community (people) cannot get access to water, there is no violation for the community.

As such, this is not enough to only consider policies and processes in the water sector, but also the combined effects of other policies in society and national development and economic policy (Humberto, 2011). Therefore, the impact of such provisions will not be the main purpose of exploiting water resources for the welfare of the community. This provision is understood by the fact of the validity of the norms that stipulate the case. The emptiness of norms means that a provision relating to one or several conditions of the law that gives an impression to society has not been determined yet. Therefore, the impression of legal uncertainty within the framework of legislation that supports the purpose of exploiting water resources to prosper society will not be realized. According to Soedikno Mertokusumo as quoted by Manullang, M (2007) that in principle, one condition must be met in implementation of the law in the community, namely the existence of legal certainty. Legal certainty refers to the provisions of the law in which there is no obscurity of norms, the vacuum of norms, as well as conflicts of norms, so as to provide legal certainty for the community to implement the law in question.

Serious attention from the drafters of legislation and the main government is to resolve the issue. This is proven by the importance of management of institutional governance in a nation. Because the originator of the current ecological crisis is not limited to human behavior in carrying out its activities. Keraf, A.S. (2002) states that the government's failure to manage a country is cause by mistakes in choosing a development model more concerned with economic growth where the development methods chosen then triggers environmental damage. The government plays a role as the guardian of common interests, including the good public interest. The failure of the government to create good governance causes deviations from various formal provisions in the field of environment along with all natural resources contained in them including water resources. Ginting states that conflicts of interest occur because of the government's low capacity and commitment to place investments in accordance with predetermined zoning (Ginting, 2011). Therefore, it is hoped that the government plays an active role in responding to the interests of all parties, especially preparing legislation as a comprehensive guide to address the needs of all parties in the field of utilization of water resources.

\section{Conclusion}

Two factors that cause conflicts of interest in the use of water resources in Indonesia. Inclusive habit of the community in utilizing water resources, which has an effect on ineffective use and the absence of the principle of balance in PP Article 2 paragraph (1) No. 121/2015 are the two dominant factors in the conflict of interest in using water resources between the community and business in Indonesia. It is recommended that the government take a proactive step to bridge these two interests and revise PPNo 121 year 2105 on the Business of Water Resources, specifically Article 2 paragraph (1) by adding the principle of balance, so that conflicts of interest between business and community interests do not continue and justice for the interests of business and society can be realized. 


\section{References}

Abdoellah, O.S. 2002. TanggungJawab Sosial M asyarakat Ilmiah dalam Menata Lingkungan Masa Depan: Upaya Meniti Pembangunan Berkelanjutan, Program Pasca Sarjana Unuversitas Padjajaran, Bandung.

Alan Nicol and Nanki Kaur, 2009. Adapting to climate change in the water sector, Overseas Development institute.

Ambar Istiyani, Dinamika Pengelolaan Sumber Daya Air di Era Otonomi Daerah Studi Kasus di Desa Tajuk, Kec.Getasan, Kab.Semarang” KRITIS, Jurnal Studi Pembangunan Interdisiplin, Vol. XXIII No. 2, 2014.

BMKG Mata Air di Aceh Kering Bukan Akibat Iklim, Banda Aceh,http://www.aktual.com/bmkg-mata-air-diaceh-kering-bukan-akibat-iklim/ mach 2018.

Chartterjee, 2000, Methods of Research in Law, Old Bailey Press, London, hlm 38 (NA-34).

C. Irena, at all., 2011, Forest, Hydrological principles for conservation of water resources within a changing forested landscape.

C.Elliot \& F. Quinn, 2001, Law for AQA, Pearson Education Limited, England.

Don Hinrichsen and Henrylito Tacio, The Coming Freshwater Crisis is Already Here, https://www.wilsoncenter.org/sites/default/files/popwawa2.pdf, April 2018

Donnelly, et al., 2012. Water as a Casualty of Conflict: Threats to Business and Society in High-Risk Areas dalam A UN-Water Analytical Brief, Water Security \& the Global Water Agenda A UN-Water Analytical Brief, United Nations University.

Falconer R.A. dan Norton. M.R. 2012. The Risk Global Report, World Economic Forum, Global Water Security: Engineering the Future

Flavin C., 2002, Starea lumii (The world state), Edit. Tehnică , Bucureşti, Romania, in: Carmen ZAHARIA, Daniela ŞUTEU, The Natural Resources And Sustainable Development, Cercetări Agronomice în Moldova Vol. XLIV, No. 1 (145),2011

Giorgio Vel Vecchio, 1982. Justice - an Historical And Philosophical Essay, Fred B. Rothman \& Co., Colorado.

George Ritzer, 2004. Sosiologi ilmu pengetahuan berparadigma ganda, terj. Alimandan, Jakarta, raja grafindo persada.

H. Sosiawan dan K. Subagyono, Strategi Pembagian Air Secara Proporsional Untuk Keberlanjutan Pemanfaatan Air, Naskah disampaikan pada Rapat Pimpinan Badan Penelitian dan Pengembangan Pertanian bulan Mei 2009.

Humberto Peña, 2011. Social Equity and Integrated Water Resources Management, Published by the Global Water Partnership, Global Water Partnership Technical Committee (TEC), No.15.

Hartati Husni, Kasie OSP UPTD I Dinas Pengairan, wawancara 10 April 2018

I Nyoman Nurdjaya, "Pengelolaan Sumberdaya Alam Berbasis Kearifan Lokal Masyarakat Hukum Adat," Gedung Cut Meutia, Kampus Bukit Indah, Program Studi Magister Ilmu Hukum Fakultas Hukum Universitas Malikussaleh (Unimal), Lhokseumawe, 8 September 2018.

Jurnal Kajian Lemhamnas RI,2011. Pengelolaan Sumber Daya Air Guna Mendukung Pembangunan Nasional Dalam Rangka Ketahanan Nasional, Jakarta.

Jie Liu dkk., 2011. Water Ethics and Water Resource Management, UNESCO, Bagkok.

Joshua Busby, 2017. Water and U.S. National Security, Discussion Paper.

Keraf, A. S. 2002.Etika Lingkungan, Penerbit Kompas, Jakarta.

Kartodihardjo, H. 2008. Pengelolaan Sumberdaya Alam (SDA) Krisis Ekologi dan Masalah di Sebaliknya, Makalah disampaikan dalam diskusi "Pengelolaan Sumber Alam dan Lingkungan Hidup: Menuju Integrasi Optimasi Manfaat antar Sektor" 29 Mei, di Fakulti Kehutanan IPB, Bogor.

Lisa Guppy and Kelsey Anderson, 2017. Global Water Crisis: The Facts, United Nations University Institute For water, Environment And Health

Munir Fuady, 1994. Hukum Bisnis Dalam Teori dan Praktek, Bandung : Citra Aditya Bakti.

Mohamad Ali Fulazzaky, Conflik of Interest Water Resources Management, Review, Jurnal Water 2014, 6, 20002020; doi:10.3390/w6072000

Prihatin, R.B. 2013. Problem Air Bersih di Perkotaan, Pusat Pengkajian, Pengolahan Data dan Informasi (P3DI) Sekretariat Jenderal DPR RI, V (7).

Priyo Utomo (ed), 1993, Pengantar Sosiologi: Buku Panduan Mahasisiwa, Jakarta, Gramedia Pustaka Utama.

Ritzer, G dan Goodman DJ. 2009. Teori Sosiologi dari Teori Sosiologi Klasik Sampai Perkembangan Mutakhir Teori Postmodern, Yogyakarta, Kreasi Wacana.

Roundtable Report, 2009. Sustainable Water Resources, CA Water Plan, Vol 4 Reference Guide.

Soedikno Mertokusumo dalam Fernando M. Manullang,2007. Menggapai Hukum Berkeadilan: Tinjauan Hukum Kodrat dan Antinomi Nilai, Jakarta

Suardana,W.G.2012. Eksploitasi Sumber Daya Air di Bali Sebabkan 
Krisis,https://www.voaindonesia.com/a/eksploitasi-sumber-daya-air-di-bali-sebab Sept 2018

Saraswaty, A.M. 2013. Kesediaan Membayar Pelanggan Rumah Tangga untuk Perkhidmatan Air Bersih dari PDAM di Kabupaten Bandung, E-Jurnal EP Unud, 2 (10).

Sallata, M.K, 2015. Konservasi dan Pengelolaan Sumber Daya Air berdasarkan keberadaanya sebagai Sumber Daya Alam, Info teknis EBONI (12) 1:76-77.

Serambi Indonesia, Proyek Pengairan Aceh Banyak Dicoret Pusat, senin 2 April 2018

The United Nations Educational, Scientificand Cultural Organization (Unesco), 2014, The United Nation World Water Development Report, Paris.

World Trade Report, 2010. Natural resources Definitions, trade paterns and globalization, World Trade Report. 